\title{
OBSERVASI KLINIK EKSTRAK LABU SIAM (Sechium edule) SEBAGAI ANTIHIPERTENSI
}

\author{
Raudhatul Munawassalmiah*, Hajrah, Laode Rijai \\ Laboratorium Penelitian dan Pengembangan Kefarmasian "Farmaka Tropis", \\ Fakultas Farmasi, Universitas Mulawarman, Samarinda, Indonesia \\ *Email: raudhatulmw@gmail.com
}

\begin{abstract}
Chayote (Sechium edule) are known to have hypotensive activity because it contain of flavonoids. The purpose of this research is to examine the effectiveness of chayote fruit extracts as antihypertensives. The method of this research is quasi experiment with equivalent time-sample design and measured pre-test and post-test blood pressure after treatment. The subjects of the reseacrh were given chayote fruit extracts with a dose of 100 $\mathrm{mL} /$ day for 7 days. The results of statistical tests showed that there were differences in the value of systolic blood pressure with a significant value of $p=0.001$ and the value of diastolic blood pressure with a significant value $p=0.009(\alpha=0.05)$. So it can be concluded that chayote fruit (Sechium edule) extracts can reduce the value of systolic and diastolic blood pressure in hypertensive patients.
\end{abstract}

Keywords: Hypertension, Chayote, Sechium edule.

\begin{abstract}
ABSTRAK
Labu Siam (Sechium edule) mengandung flavonoid yang diketahui memiliki aktivitas hipotensi. Tujuan penelitian ini adalah untuk mengetahui adanya pengaruh pemberian ekstrak buah labu siam sebagai antihipertensi. Metode penelitian ini adalah eksperimen semu (quasy experiment) dengan desain equivalent time-sample design yang dilakukan dengan cara memberikan perlakuan dan diukur tekanan darah pre-test dan post-test. Subjek penelitian diberikan ekstrak labu siam dengan dosis $100 \mathrm{~mL} /$ hari selama 7 hari. Hasil uji statistik menunjukkan terdapat perbedaan nilai tekanan darah sistolik dengan nilai signifikan $\mathrm{p}=0,001$ dan nilai tekanan darah diastolik dengan nilai signifikan $\mathrm{p}=0,009$ $(\alpha=0,05)$. Sehingga dapat disimpulkan bahwa labu siam (Sechium edule) dapat menurunkan nilai tekanan darah sistolik dan diastolik pada pasien hipertensi.
\end{abstract}

Kata kunci: Hipertensi, Labu Siam, Sechium edule.

DOI: https://doi.org/10.25026/mpc.v8i1.314 


\section{PENDAHULUAN}

WHO (World Health Organization) mencatat pada tahun 2013 sedikitnya sejumlah 972 juta kasus hipertensi, diperkirakan menjadi 1,15 milyar kasus pada tahun 2025 atau sekitaran $29 \%$ dari total penduduk dunia menderita hipertensi, dimana 333 juta berada di negara maju dan 639 sisanya berada di negara berkembang termasuk Indonesia, sekitar $80 \%$ kenaikan kasus hipertensi terjadi terutama di negara berkembang. Hipertensi juga menempati peringkat ke2 dari 10 penyakit terbanyak pada pasien rawat jalan dirumah sakit di Indonesia ${ }^{[17]}$.

Peningkatan tekanan darah yang berlangsung dalam jangka waktu lama (persisten) dapat menyebabkan kerusakan pada ginjal (gagal ginjal), jantung (penyakit jantung koroner), dan otak (stroke) bila tidak terdeteksi secara dini dan mendapat pengobatan yang memadai. Hipertensi juga dapat menyebabkan berbagai komplikasi ${ }^{[19]}$. Komplikasi hipertensi menyebabkan sekitar 9,4 kematian di seluruh dunia setiap tahunnya dan diperkirakan akan terus meningkat mencapai 23,3 juta kematian pada tahun $2030^{[8]}$. Maka perlu dilakukan pengendalian tekanan darah untuk mengatasi hipertensi, hal ini dapat dilakukan secara farmakologi dan non farmakologi. Penanganan secara farmakologi dapat diberi obat-obat hipertensi berupa diuretik, betabloker, ACE inhibitor, angiotensin II receptor blocker, antagonis kalsium, vasodilator $^{[13]}$.

Saat ini penggunaan bahan alam, baik sebagai obat maupun tujuan lain cenderung meningkat, terlebih dengan adanya istilah back to nature. Obat tradisional dan tanaman obat banyak digunakan di masyarakat menengah ke bawah terutama dalam upaya preventif, promotif, dan rehabilitatif. Sementara ini banyak orang beranggapan penggunaan tanaman obat atau obat tradisional lebih aman dibandingkan obat sintetis. Umumnya khasiat obat-obat tradisional sampai saat ini hanya didasarkan pada pengalaman empiris dan belum teruji secara ilmiah $^{[7]}$.

Terapi menggunakan obat herbal merupakan salah satu cara penanganan hipertensi. Terapi herbal dilakukan dengan menggunakan obat-obatan herbal atau tanaman obat. Salah satunya adalah dengan menggunakan buah labu siam (Sechium edule). Buah labu siam (Sechium edule) mengandung beberapa senyawa kimia yaitu alkaloid, saponin, dan flavonoid ${ }^{[18]}$.

Salah satu senyawa aktif yang terdapat pada labu siam (Sechium edule) adalah flavonoid. Flavonoid memiliki efek hipotensi dengan mekanisme menghambat aktivitas ACE, serta sebagai diuretik $^{[10]}$. Diketahui ACE memegang peran dalam pembentukan angiotensin II yang merupakan salah satu penyebab hipertensi. Angiotensin II menyebabkan pembuluh darah melebar sehingga darah lebih banyak mengalir ke jantung, mengakibatkan penurunan tekanan darah $^{[2]}$. Selain itu, flavonoid dapat meningkatkan urinasi dan pengeluaran elektrolit, yang mana berfungsi layaknya kalium, yaitu mengabsorbsi cairan ionion elektrolit seperti natrium yang ada di dalam intraseluler darah untuk menuju ekstraseluler memasuki tubulus ginjal. Glomerular Filtration Rate (GFR) yang tinggi akibat adanya aktivitas flavonoid menyebabkan ginjal mampu mengeluarkan produk buangan dari tubuh dengan cepat ${ }^{[12]}$.

Berdasarkan uraian latar belakang tersebut, maka dilakukan penelitian untuk mengetahui adanya pengaruh pemberian ekstrak labu siam (Sechium edule) sebagai antihipertensi.

\section{METODE PENELITIAN}

Metodelogi penelitian yang digunakan adalah penelitian eksperimen semu (quasy experiment) dengan rancangan penelitian equivalent timesample design. Penelitian ini dilakukan dengan cara memberikan perlakuan yang 
diawali dengan pre-test, dan seteleh pemberian perlakuan diadakan pengukuran kembali (post-test).

Populasi dalam penelitian ini adalah penderita hipertensi pada kelompok usia 30-50 tahun yang tercatat dalam buku registrasi pasien di Puskesmas Sempaja Samarinda Kalimantan Timur pada bulan Januari sampai bulan Agustus pada tahun 2018.

Sampel dalam penelitian ini diambil berdasarkan kriteria inklusi, yaitu: (a) Mengalami hipertensi primer (esensial) (b) Mengalami hipertensi stage 1 (c) Usia 30-50 tahun (d) Bersedia menjadi subjek penelitian (e) Dapat berkomunikasi aktif secara verbal (f) Pasien hipertensi tanpa penyakit penyerta (g) Pasien hipertensi tanpa komplikasi (h) Pasien hipertensi yang menerima pengobatan antihipertensi (i) Tidak menjalani terapi komplementer lainnya, dan dengan kriteria eksklusi yaitu: (a) Pasien yang memiliki alergi terhadap sampel (b) Pasien yang tidak patuh mengkonsumsi obat. Pengambilan sampel dalam penelitian ini dilakukan menggunakan teknik non probability sampling dengan cara purposive sampling, dimana pengambilan sampel dilakukan berdasarkan pertimbangan peneliti sendiri.

Instrumen penelitian yang digunakan dalam penelitian ini adalah (1) Ekstrak air labu siam (Sechium edule) yang dibuat dengan cara diparut lalu disaring dan diambil air sarinya dan diberikan pada kelompok intervensi dengan dosis $100 \mathrm{~mL} /$ hari selama 7 hari (2) Form pengumpul data untuk mengumpulkan data pasien meliputi usia, jenis kelamin, pendidikan, dan obat yang digunakan (3) Tensimeter automatik untuk mengukur tekanan darah pasien (4) Parutan untuk memarut buah labu siam (Sechium edule) (5) Saringan untuk menyaring sari buah labu siam (Sechium edule) (6) Gelas sebagai wadah ekstrak labu siam (7) Informed consent sebbagai bukti fisik persetujuan menjadi responden penelitian (8) Alat dokumentasi (9) Alat tulis dan komputer untuk mengolah data yang telah diperoleh.

Data penelitian yang digunakan dalam penelitian ini berupa sumber data primer yang berasal dari pengumpulan data secara langsung, dimana peneliti akan mewawancarai dan mengukur tekanan darah pasien secara langsung.

\section{HASIL DAN PEMBAHASAN}

Tekanan darah adalah tekanan yang ditimbulkan pada dinding arteri. Tekanan puncak terjadi pada saat ventrikel berkontraksi yang disebut dengan tekanan darah sistolik. Sedangkan tekanan darah terendah yang terjadi pada saat jantung beristirahat disebut dengan tekanan darah diastolik. Tekanan darah biasanya digambarkan sebagai rasio tekanan sistolik terhadap tekanan diastolik, dengan nilai normal pada orang dewasa berkisar dari 100/60 sampai 140/90 $\mathrm{mmHg}$. Umumnya tekanan darah normal adalah $120 / 80 \mathrm{mmHg}^{[4]}$.

Hipertensi adalah penyakit yang didefinisikan sebagai peningkatan tekanan darah secara menetap. Pada umumnya, seseorang dikatakan mengalami hipertensi jika tekanan darah berada di atas $140 / 90 \mathrm{mmHg}^{[3]}$.

Penelitian ini bertujuan untuk mengetahui pengaruh ekstrak labu siam (Sechium edule) terhadap penurunan tekanan darah pasien hipertensi. Responden diberikan intervensi ekstrak air labu siam (Sechium edule) yang berperan sebagai terapi komplementer, dimana responden mengonsumsi obat sintetik sebagai terapi farmakologi dan dikombinasi dengan ekstrak air labu siam (Sechium edule) sebagai terapi non farmakologi.

Adapun hasil penelitian untuk mengetahui pengaruh pemberian ekstrak labu siam (Sechium edule) pada pasien hipertensi pada tekanan darah sistolik dapat dilihat pada Tabel 1 dan Gambar 1 . 
Tabel 1. Distribusi Responden Berdasarkan Hasil Pengukuran Nilai Tekanan Darah Sistolik Sebelum (Pre-Test) dan Sesudah (Post-Test) Perlakuan

\begin{tabular}{ccccc}
\hline \multirow{2}{*}{ Responden } & \multicolumn{2}{c}{ Hasil Pengukuran $(\mathrm{mmHg})$} & $\begin{array}{c}\text { Nilai } \\
\text { Selisih }(\Delta)\end{array}$ & $\begin{array}{c}\text { Nilai P } \\
(<0,05)\end{array}$ \\
\cline { 2 - 3 } IR & Sebelum(pre-test $)$ & Sesudah(post-test $)$ & 39 & \\
MD & 169 & 130 & 16 & \\
FT & 146 & 130 & 2 & \\
FR & 132 & 130 & 15 & \\
WT & 170 & 155 & 19 & 0,001 \\
DY & 159 & 140 & 18 & \\
AS & 176 & 158 & 12 & \\
MS & 142 & 130 & 29 & \\
PN & 149 & 120 & 40 & \\
\hline
\end{tabular}

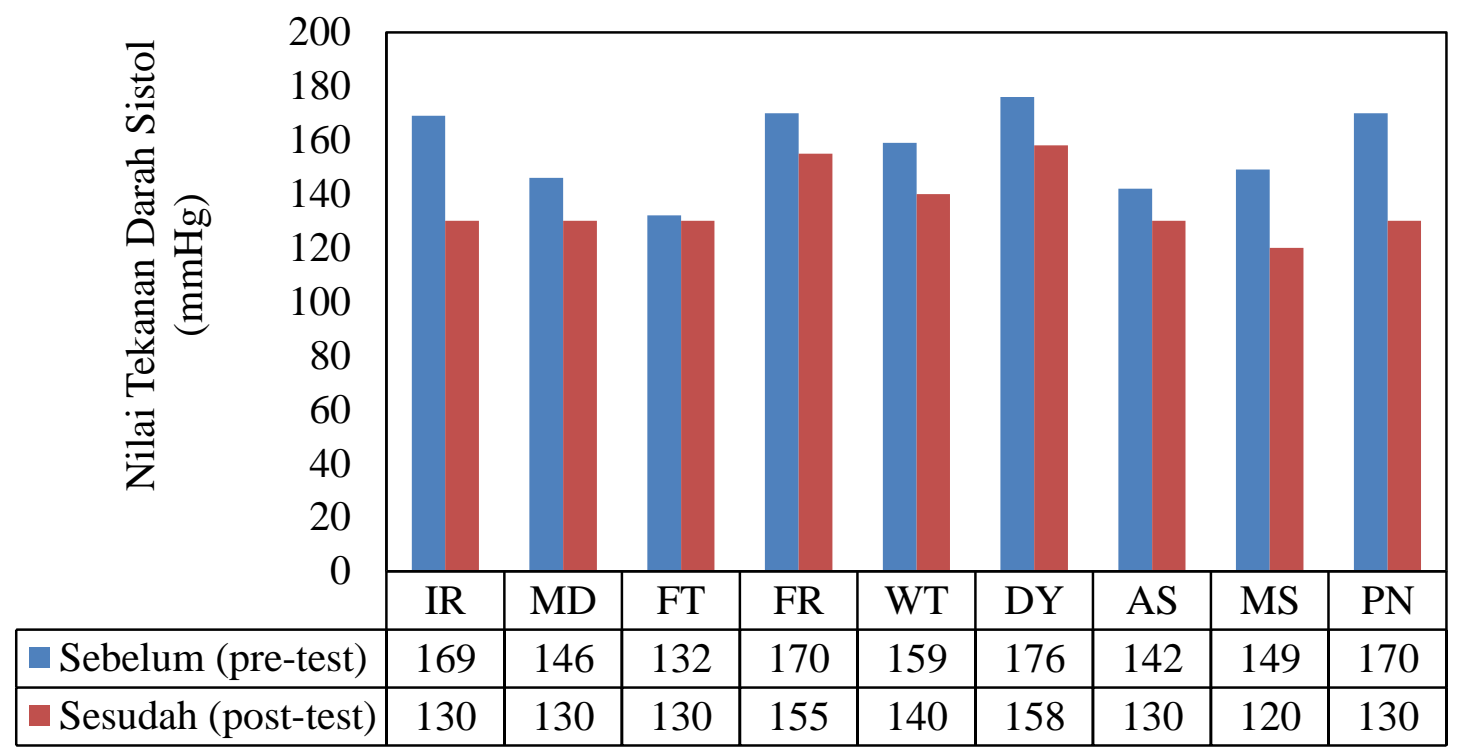

Gambar 1. Distribusi Responden Berdasarkan Hasil Pengukuran Nilai Tekanan Darah Sistolik Sebelum (Pre-Test) dan Sesudah (Post-Test) Perlakuan

Berdasarkan hasil penelitian yang diperoleh pada Tabel 1 dan Gambar 1 menunjukkan bahwa terjadi penurunan nilai tekanan darah sistolik sebelum (pretest) perlakuan dan setelah (post-test) perlakuan atau intervensi dengan ekstrak labu siam (Sechium edule). Dimana nilai tekanan darah sistolik rata-rata pada semua responden terjadi penurunan tekanan darah. Nilai penurunan tekanan darah sistolik paling signifikan dari semua reponden terdapat pada responden dengan kode IR dengan nilai tekanan darah sistolik sebelum intervensi yaitu $169 \mathrm{mmHg}$ dan sesudah intervensi yaitu $130 \mathrm{mmHg}$ dengan nilai selisih 39 $\mathrm{mmHg}$, dan pada responden dengan kode MS dengan nilai tekanan darah sistolik sebelum intervensi yaitu $149 \mathrm{mmHg}$ dan sesudah intervensi yaitu $120 \mathrm{mmHg}$ dengan nilai selisih $29 \mathrm{mmHg}$, serta pada responden dengan kode PN dengan nilai tekanan darah sistolik sebelum intervensi yaitu $170 \mathrm{mmHg}$ dan sesudah intervensi yaitu $130 \mathrm{mmHg}$ dengan nilai selisih 40 $\mathrm{mmHg}$. 
Hal tersebut juga diperkuat dengan hasil analisis data menggunakan SPSS dengan metode uji $\mathrm{T}$ sampel berpasangan (Paired T-Test), dimana rata-rata nilai penurunan tekanan darah sistolik responden sebelum (pre-test) perlakuan dan setelah (post-test) perlakuan atau intervensi dengan ekstrak labu siam (Sechium edule) menunjukkan nilai signifikan dengan nilai $\mathrm{p}$ value yaitu 0,001. Dari data tersebut maka diperoleh nilai $\mathrm{p}=0,001$ yang lebih kecil dari nilai $\alpha=0,05$, yang berarti bahwa ada perbedaan tekanan darah sistolik yang signifikan sebelum dan sesudah perlakuan pada masing-masing responden. Sehingga dapat disimpulkan bahwa ekstrak labu siam (Sechium edule) berpengaruh pada penurunan tekanan darah sistolik pasien hipertensi.

Penurunan tekanan darah sistolik pada pasien yang mengonsumsi obat sintetik dan ekstrak labu siam (Sechium edule) sebagai terapi komplementer diduga karena adanya efek sinergis dari obat konvensional dan labu siam (Sechium edule). Hal ini juga diduga disebabkan oleh senyawa aktif yang terdapat pada buah labu siam (Sechium edule) yaitu flavonoid. Kandungan flavonoid pada labu siam (Sechium edule) dikaitkan dengan efek perlindungan terhadap fungsi endotel dan menghambat agregasi platelet, sehingga dapat menurunkan resiko penyakit jantung koroner dan penyakit kardiovaskuler ${ }^{[6]}$. Flavonoid memiliki efek hipotensi dengan mekanisme menghambat aktivitas ACE, serta sebagai diuretik ${ }^{[11]}$.

Flavonoid dapat menghambat ACE. Dimana diketahui ACE memegang peranan penting dalam pembentukan angiotensin II yang merupakan salah satu penyebab yang berperan pada terjadinya penyakit hipertensi. Angiotensin II menyebabkan pembuluh darah menyempit, yang dapat menaikkan tekanan darah. ACE inhibitor menyebabkan pembuluh darah melebar sehingga darah lebih banyak mengalir ke jantung yang mengakibatkan terjadinya penurunan tekanan darah ${ }^{[2]}$. Selain itu, flavonoid juga dapat meningkatkan urinasi dan pengeluaran elektrolit, yang mana dapat berfungsi layaknya kalium, yaitu mengabsorbsi cairan ion-ion elektrolit seperti natrium yang ada di dalam intraseluler darah untuk menuju ekstraseluler memasuki tubulus ginjal. Glomerular Filtration Rate (GFR) yang tinggi akibat adanya aktivitas flavonoid menyebabkan ginjal mampu mengeluarkan produk buangan dari tubuh dengan cepat ${ }^{[15]}$.

Adapun hasil penelitian untuk mengetahui pengaruh pemberian ekstrak labu siam (Sechium edule) pada pasien hipertensi pada tekanan darah diastolik dapat dilihat pada Tabel 2 dan Gambar 2.

Tabel 2. Distribusi Responden Berdasarkan Hasil Pengukuran Nilai Tekanan Darah Diastolik Sebelum (Pre-Test) dan Sesudah (Post-Test) Perlakuan

\begin{tabular}{|c|c|c|c|c|}
\hline \multirow{2}{*}{ Responden } & \multicolumn{2}{|c|}{ Hasil Pengukuran (mmHg) } & \multirow{2}{*}{$\begin{array}{c}\text { Nilai Selisih } \\
(\Delta)\end{array}$} & \multirow{2}{*}{$\begin{array}{l}\text { Nilai P } \\
(<0,05)\end{array}$} \\
\hline & Sebelum (pre-test) & Sesudah (post-test) & & \\
\hline IR & 110 & 88 & 22 & \\
\hline MD & 99 & 85 & 14 & \\
\hline FT & 120 & 85 & 35 & \\
\hline FR & 96 & 90 & 6 & \\
\hline WT & 109 & 110 & -1 & 0,009 \\
\hline DY & 97 & 90 & 7 & \\
\hline AS & 92 & 89 & 3 & \\
\hline MS & 90 & 80 & 10 & \\
\hline PN & 110 & 85 & 25 & \\
\hline
\end{tabular}




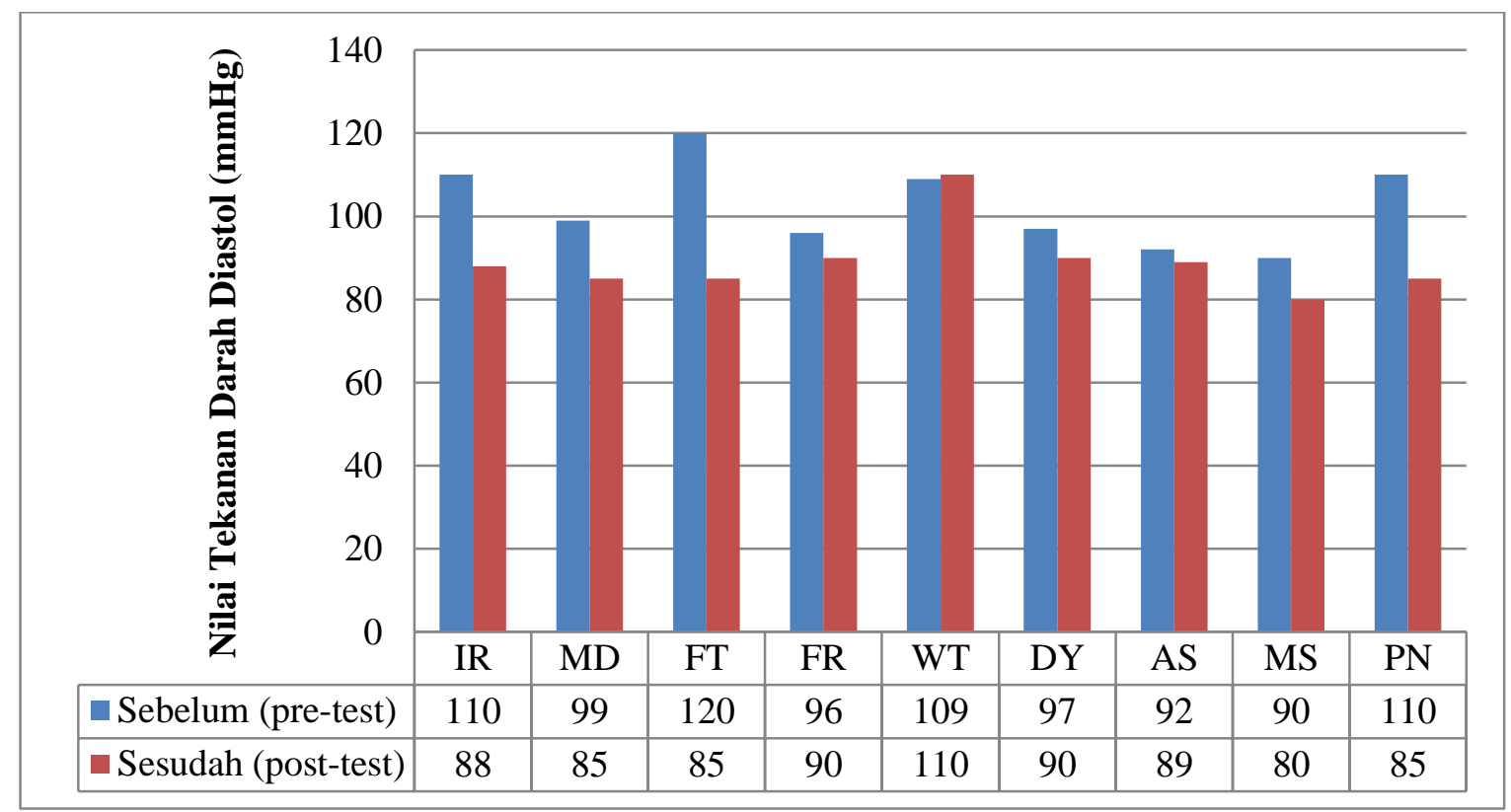

Gambar 2. Distribusi Responden Berdasarkan Hasil Pengukuran Nilai Tekanan Darah Diastolik Sebelum (Pre-Test) dan Sesudah (Post-Test) Perlakuan

Berdasarkan hasil penelitian yang diperoleh pada Tabel 2 dan Gambar 2 menunjukkan bahwa terjadi penurunan nilai tekanan darah diastolik sebelum (pre-test) perlakuan dan setelah (posttest) perlakuan atau intervensi dengan ekstrak labu siam (Sechium edule). Dimana nilai tekanan darah diastolik ratarata responden terjadi penurunan tekanan darah. Nilai penurunan tekanan darah diastolik paling signifikan dari semua reponden terdapat pada responden dengan kode IR dengan nilai tekanan darah diastolik sebelum intervensi yaitu 110 $\mathrm{mmHg}$ dan sesudah intervensi yaitu 88 $\mathrm{mmHg}$ dengan nilai selisih $22 \mathrm{mmHg}$, dan pada responden dengan kode FT dengan nilai tekanan darah diastolik sebelum intervensi yaitu $120 \mathrm{mmHg}$ dan sesudah intervensi yaitu $85 \mathrm{mmHg}$ dengan nilai selisish $35 \mathrm{mmHg}$, serta pada responden dengan kode PN dengan nilai tekanan darah diastolik sebelum intervensi $110 \mathrm{mmHg}$ dan sesudah intervensi $85 \mathrm{mmHg}$ dengan nilai selisih $25 \mathrm{mmHg}$.

Hal ini juga diperkuat dengan hasil analisis data menggunakan SPSS metode uji $\mathrm{T}$ sampel berpasangan (Paired $T$ Test), rata-rata nilai penurunan tekanan darah diastolik responden sebelum (pretest) perlakuan dan setelah (post-test) perlakuan atau intervensi dengan ekstrak labu siam menunjukkan nilai signifikan dengan $\mathrm{p}$ value yaitu 0,009. Dari data tersebut maka diperoleh nilai $\mathrm{p}=0,009$ yang lebih kecil dari nilai $\alpha=0,05$ yang berarti bahwa ada perbedaan tekanan darah diastolik yang signifikan sebelum dan sesudah perlakuan pada masingmasing responden. Sehingga dapat disimpulkan bahwa ekstrak labu siam (Sechium edule) berpengaruh pada penurunan tekanan darah diastolik pasien hipertensi.

Adanya penurunan tekanan darah diastolik pada pasien hipertensi yang diberikan ekstrak labu siam (Sechium edule) sebagai terapi komplementer, dimana ekstrak labu siam (Sechium edule) digunakan sebagai terapi tambahan yang dikombinasi dengan terapi farmakologi berupa obat konvensional atau obat sintetik. Penurunan tekanan darah diastolik yang terjadi diduga karena adanya efek sinergis dari obat 
konvensional dan labu siam (Sechium edule). Hal itu juga disebabkan oleh adanya kandungan kalium dan alkaloid pada labu siam (Sechium edule) yang beraktivitas sebagai diuretik yaitu membantu ginjal mengeluarkan kelebihan cairan dan garam dari dalam tubuh, sehingga berkurangnya cairan dalam darah akan menurunkan tekanan darah ${ }^{[16]}$.

Selain itu, manfaat kalium dalam labu siam (Sechium edule) dapat mengurangi sekresi renin yang menyebabkan penurunan angiotensin II sehingga vasokonstriksi pembuluh darah berkurang dan menurunnya aldosteron sehingga reabsorbsi natrium dan air ke dalam darah berkurang. Kalium juga memiliki efek pompa Na-K yaitu kalium dipompa dari cairan ekstraseluler ke dalam sel, sedangkan natrium dipompa keluar sehingga kalium dapat menurunkan tekanan darah. Buah labu siam (Sechium edule) juga mengandung zat saponin, tanin, alkaloid, serta flavonoid $^{[5]}$.

Namun, pada responden dengan kode WT terjadi kenaikan nilai tekanan darah diastolik sebelum intervensi yaitu $109 \mathrm{mmHg}$ dan sesudah intervensi yaitu $110 \mathrm{mmHg}$ dengan kenaikan tekanan darah sebesar $1 \mathrm{mmHg}$. Dan setelah dilakukan wawancara pada responden diketahui bahwa responden mengalami stres.

Umumnya tekanan darah tinggi dapat disebabkan oleh berbagai macam faktor, salah satunya adalah faktor stres. Stres merupakan suatu respon nonspesifik dari tubuh terhadap setiap tekanan atau tuntutan yang mungkin muncul, baik dari kondisi yang menyenangkan maupun tidak menyenangkan ${ }^{[14]}$.

Stres merupakan faktor yang dapat memicu timbulnya hipertensi melalui aktivitas sistem saraf simpatis yang mengakibatkan naiknya tekanan darah secara intermiten (tidak menentu) ${ }^{[1]}$. Stres merupakan rasa takut atau cemas dari perasaan dan tubuh seseorang terhadap adanya perubahan dari lingkungan. Apabila ada sesuatu hal yang mengancam secara fisiologis, kelenjar pituitary otak akan mengirimkan hormon kelenjar endokrim ke dalam darah, hormon ini berfungsi untuk mengaktifkan hormon adrenalin dan hidrokortison, sehingga membuat tubuh dapat menyesuaikan diri terhadap perubahan yang terjadi. Kondisi stres yang membuat tubuh menghasilkan hormon adrenalin lebih banyak, membuat jantung bekerja lebih kuat dan cepat. Apabila terjadi dalam waktu yang lama maka akan timbul rangkaian reaksi dari organ tubuh lain. Perubahan fungsional tekanan darah yang disebabkan oleh kondisi stres dapat menyebabkan hipertropi kardiovaskuler bila berulang secara intermiten. Begitupula stres yang dialami penderita hipertensi, maka akan mempengaruhi peningkatan tekanan darah yang cenderung menetap atau bahkan dapat bertambah tinggi sehingga menyebabkan kondisi hipertensi yang lebih berat ${ }^{[9]}$.

\section{KESIMPULAN}

Ada perbedaan tekanan darah sistolik dan diastolik sebelum dan sesudah perlakuan, sehingga dapat disimpulkan bahwa perlakuan berupa pemberian ekstrak labu siam (Sechium edule) berpengaruh terhadap penurunan tekanan darah pasien hipertensi.

\section{UCAPAN TERIMA KASIH}

Penulis menyampaikan rasa terima kasih kepada responden penelitian serta pegawai Puskesmas Sempaja Samarinda.

\section{DAFTAR PUSTAKA}

[1] Andria, K.M. 2013. Hubungan antara Perilaku Olahraga, Stres dan Pola Makan dengan Tingkat Hipertensi pada Lanjut Usia di Posyandu Lansia Kelurahan Gebang Putih Kecamatan Sukokilo Kota Surabaya. Jurnal Promkes, Vol.1,No.2.

[2] Balasuriya BWN, Rupasinghe HPN. Plant flavonoids as angiotensin 
converting enzyme inhibitors in regulation of hypertension. FFHD. 2011;5:172-188.

[3] Dharmeizar. 2012. Hipertensi. Medicinus: Scientific Journal of Pharmaceutical Development and Medical Application. Vol.25., No.1.

[4] Dinkes Prov. Sultra. 2015. Profil Dinas Kesehatan Provinsi Sulawesi Tenggara. Kendari.

[5] Gunawan, D. 2012. Ilmu Obat Alam (Farmakognosi). Jilid I. Jakarta: Penebar Swadaya.

[6] Ismiyati. Aktivitas antihipertensi ekstrak etanol daun salam (Syzygium polyanthum) pada tikus wistar, profil kromatografi lapis tipis serta penetapan kandungan fenolik total dan flavonoid totalnya [tesis]. Yogyakarta (Indonesia): Fakultas Farmasi Universitas Gadjah Mada; 2013. hlm. 3-5.

[7] Katno, Pramono S. 2009. Tingkat Manfaat dan Keamanan Tanaman Obat dan Obat Tradisional. Yogyakarta: Fakultas Farmasi UGM.

[8] Kemenkes RI. 2015. Profil Kesehatan Indonesia Tahun 2014. Jakarta: Kemenkes Republik Indonesia.

[9] Lawson, RW., Arthur, J., BarskyVictor, RG., Kaplan, NM. 2007. Systemic Hypertension: Mechanisms and Diagnosis. Philadelphia: Saunders Elsevier.

[10]Nurdiantami, Y. 2013. Efek Penghambatan Aktivitas Angiotensin I Converting Enzyme dari Beberapa Tanaman di Indonesia yang Digunakan sebagai Antihipertensi. Depok: Fakultas Farmasi Universitas Indonesia.
[11]Panjaitan RGP, Bintang M. Peningkatan kandungan kalium urin setelah pemberian ekstrak sari buah belimbing manis (Averrhoa carambola). Jurnal Veteriner. 2014;15(1):108-13.

[12]Rao, K.N.V., et all. 2011. Diuretic Activity On Different Extracts and Formulation On Aerial Parts Of Rumex Vesicarius. Linn. J Chem Pharm Res. 3(6):400-40.

[13]Rusdi. 2009. Awas! Bisa Mati Cepat Akibat Hipertensi dan Diabetes. Yogyakarta: Power Books (IHDINA).

[14] Sadock, B.J. \& Sadock, V.A., 2003. Kaplan \& Sadock's Synopsis of Psychiatry (9th ed.). Philadelphia: Williams \& Wilkins.

[15] Septian BA, Widyaningsih TD. Peranan senyawa bioaktif minuman cincau hitam (mesona palustris bl.) terhadap penurunan tekanan darah tinggi. Jurnal Pangan dan Agroindustri. 2014;2(3):198-202.

[16] Sudibyo, A. 2014. Efek Jus Buah Labu Siam (Sechium Edule Swartz) Terhadap Tekanan Darah Normal Laki-Laki Dewasa.Jurnal: Universitas Muhammadiyah Surakarta. Volume. 1. No.4.

[17] Triyanto, Endang. 2014. Pelayanan Keperawatan Bagi Penderita Hipertensi Secara Terpadu. Yogyakarta: Graha Ilmu.

[18] Walanda, D.K. dan Rahma N. 2012. Penentuan Kadar Kalium (K) dan Kalsium (Ca) dalam Labu Siam (Sechium edule) serta Pengaruh Tempat Tumbuhnya. J. Akad Kim. 1(4):174-80.

[19] Yonata, Ade dan Arif Satria Putra Pratama. 2016. Hipertensi sebagai Faktor Pencetus Terjadinya Stroke. Majority. Vol.5. No.3. 